attending the ordinary mode of calculating the same force, and proposed instead a method requiring for its application only the use of the dip-circle, a vast advantage to the traveller, as it reduced to the smallest possible number the instruments which he would have to carry.

Along with his friend Sabine he visited the chief Continental cities in 1839, going as far as Berlin. This tour was altogether undertaken for the purposes of establishing still further a system of joint records of magnetical phenomena. His chief work in connection with magnetism was published under the title of "The Dublin Magnetical and Meteorological Observations" ( 2 vols. 4to, 1865-69). In 1857, when the British Association visited Dublin for a second time, Lloyd was their president, and many will still remember his dignified and courteous behaviour as such.

When, in 1867 , Dr. Lloyd was appointed provost, there was scarcely one dissentient voice. He had distinguished himself in his college career; his researches had reflected lustre on his university, and the belief in him was never shaken. During his period of office as Senior Fellow the study of the experimental sciences was introduced into the curriculum; in $185 \mathrm{I}$ it was even possibie to graduate as a Gold Medallist in these. To the experimental sciences were at first joined the natural sciences. During his provostship, these two groups were separated, to the great encouragement of the students in both. It was something wonderful to find how the now aged provost kept pace with the time, encouraging in every way the more modern view of things. Among the Professors and Fellows of his college he was very popular; he was always affable, while he possessed a quiet dignity. Proudly conscious of the position he held as Provost of Trinity College, he was singularly unambitious of worldly honours, but the honorary degree of D.C.L. from the sister University of Oxford, conferred on him in 1856 , was grateful to him, and he always spoke with pleasure of the recognition of his scientific merits by the Emperor of Germany, who conferred on him in .1874 the order "Pour le Mérite;" he was a F.R.SS. Lond. and Edin. He received the Cunningham gold medal of the Royal Irish Academy in 1862 .

\section{GEOLOGISING AT SHEPPEY}

SO much has been said about the abundance of fossil fruits at Sheppey that most geologists picture them lying plentifully upon the shore waiting to be picked up, and their only concern might well be at the outset to provide baskets strong and ample enough to convey their collectings home. A day spent $u_{2}$ on the beash would dispel these preconceived ideas.

The cliffs in a wet season are streams of liquid mud alternating with freshly-fallen landslips rendering them practically unapproachable. The wet and frost have this year proved exceptionally disastrous, and mere shreds of coast-paths remain. In places slabs of freshly-ploughed land are arrested half-way down the cliff, and at one point a cabbage-garden with the produce still only partly cut is streaming down to the beach. It is a good time for the cement works, but when Roman cement falls into disuse, as it seems likely to, then perhaps steps will be taken to stay this perpetual removal of fine arable land into the channels of the Thames. The beach itself is gravelly, and at low water there are extensive mud-flats. Among the gravel are patches of rolled pyrites, and among these pyrites the fruits are found, though valuable specimens are rare. This Christmas five experienced collectors, including Mr. W. H. Shrubsole, F.G.S., Mr. O. A. Shrubsole, F.G.S., Dr. Häusler, F.G.S., myself and brother, searched for several hours without a single fairly perfect fruit being found, and no greater success attended us on subsequent days. The vast bulk of the pyrites is amorphous; the majority of that which retains any recognisable shape is made up of twigs ; a consider able percentage is of nearly obliterated casts of shells ; and here and there are broken up Nipadites and other water-worn fragments of fruits. The best way to collect is to lie down upon the pyrites and examine it closely, when seeds and twigs that are passed over by the copperas-gatherers may be picked out. In this way I found seeds and scales of Araucaria, twigs of Ephedra, and many other shapes that may some day be recognised as parts of still-existing plants. No rest, short of doing absolutely nothing, could be more perfect to an overworked geologist's brain than to sprawl and smoke upon this beach.

The fruits themselves are so rare in the London Clay that they are seldom if ever found in situ, no prolific patches are known, and to attempt to dig for them would be futile. Their abundance in collections is due to the facts that for several miles there are lofty cliffs perpetually wasting away, and that the whole of the clay that reaches the beach is slowly removed in suspension by the sea, every particle of pyrites remaining behind until picked up for copperas or dissolved away. For two hundred years they have been known and searched for daily by the septaria and copperas collectors, and any one may quickly purchase an extensive collection. I have within a few months received from my friend Mr. Shrubsole enough Nipadites to fill a twenty-gallon cask, besides other fruits innumerable. Bowerbank's collection numbers many thousands, 300 specimens of a rare cone alone from Herne Bay having been in his possession. There is in the British Museum a MS. catalogue by a Mr. Crowe of Faversham, with $83 \mathrm{I}$ very rough drawings representing, as he supposed, 700 varieties. Ettingshausen, when he examined the British Museum collection, made 200 species. How many there may really be is still unknown, but the number doubtless is very considerably beyond the latter. Among the Coniferæ alone I have to add, besides the Ephedra, a Podocarpus near to $P$. elata, a Frenella almost indistinguishable from $F$. Endlicheri, and an Araucaria near $A$. Cunninghami. I have grave doubts about the correctness of the determination of all the other Coniferæ except a few of Bowerbank's Cupressineæ, and am still at work upon them. The state in which they are preserved is not sufficiently taken into account. The woody matter is generally preserved as lignite, and easily removed when rolled upon the beach, and the pyrites which remains filled the cavities between the more solid parts, as well as replacing the fruit itself. The densest and most salient part now is the purest pyrites, and was therefore at the time of fossilisation probably the most open part of the fruit or the filling in of cavities. The casts that are found are thus, in the case of hardshelled fruits, more often casts of the space between the outer ligneous shell and the kernel, than of either the kernel or the shell itself. In the case, for instance, of an almon l, we should have most frequently a smooth cast of the inside of the shell, but in perfect fruits the pitted exterior would be preserved, and in fruits partially dissolved the wrinkled kernel would show. In fruits with septa the variety of aspect presented in different stages of preservation is very great, and has doubtless led to the same species being catalogued under several names. The so-called Sequoia or Petrophiloides of Herne Bay is another instance, for the filling-in between the open scales of the cone was thought by Bowerbank to represent confluent scales inclosing cells, the supposed cells being really the cavities left by the true scales which have decayed away, while the infiltrated pyrites has enveloped the seeds which lay under them.

On Monday we took the 8 a.m. train to Herne Bay and searched at Swalecliffe for cones. At Whitstable we set sail in an oyster-boat for Shellness, but some delay occurred in getting it off the ground; the wind dropped in the meantime, and we had to row. Shellness 
was reached at dusk, and we experienced some difficulty in landing across the mud, which stretches a long way from shore at low water. We reached Warden Point at 6, and found that the fly we expected to meet us bad driven home an hour before. The position of two mud-covered and complete strangers on a dark night on a most desolate spot, in drenching rain, eight miles from, and two hours late for dinner was not particularly enviable; yet a well-arranged excursion from Whitstable to Sheerness, via the singular shores of Shellness, would under pleasanter circumstances well repay any naturalist. J. STARKIE GARDNER

\section{THE CONSERVATOIRE DES ARTS ET $M E T I E R S^{1}$}

$\mathrm{NE}$ of the most eminent English men of science said to us one day:- "You have at Paris collections, libraries, museums, observatories, faculties, schools; we have the equivalent of all that. There is only one thing we have not, which I always admire among you, and that is the Conservatoire des Arts et Métiers.'

The National Conservatoire des Arts et Métiers ${ }^{2}$ is, in fact, an establishment unique of its kind both in its scientific interest and practical utility. No institution is more

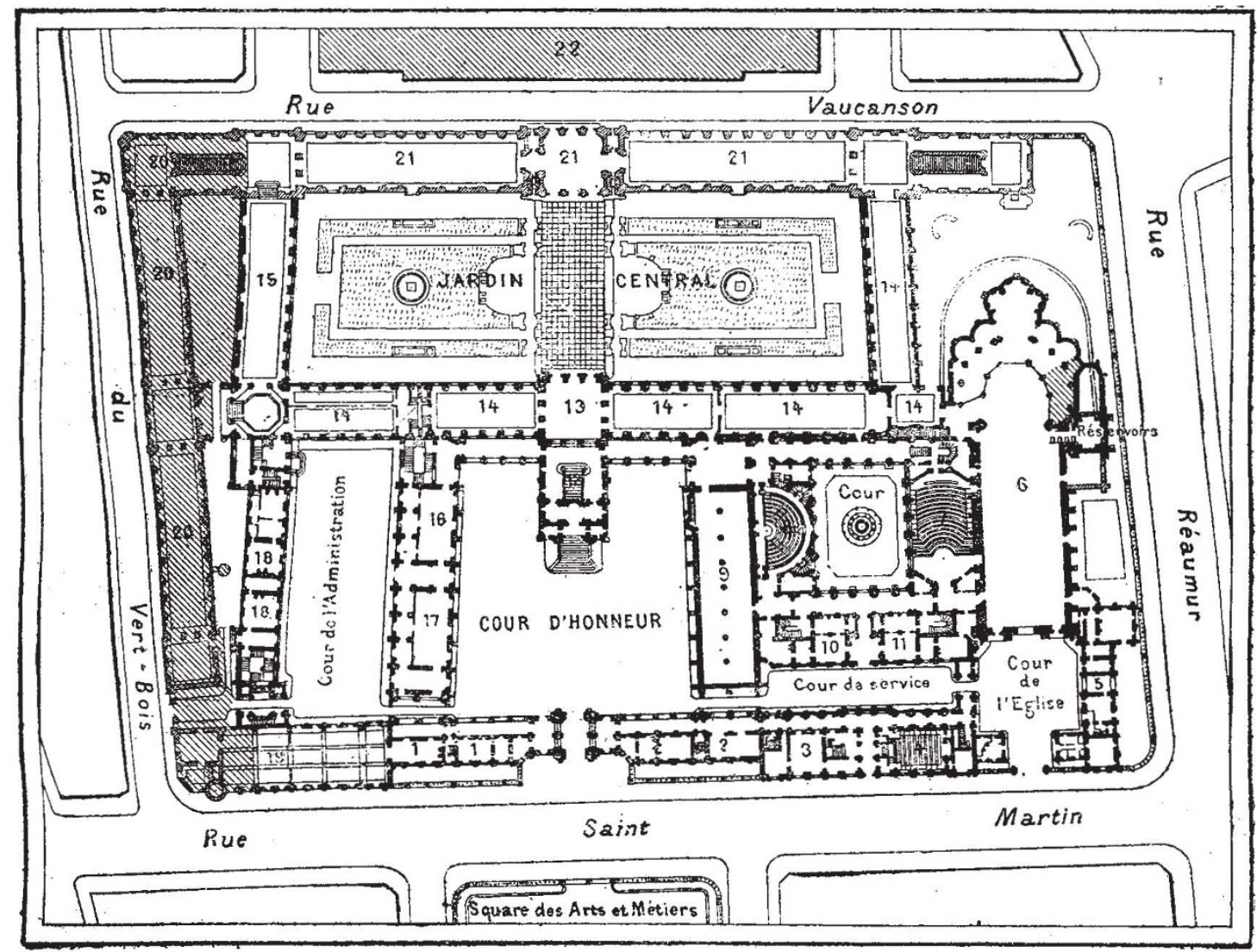

FIG. I. - Plan of the Conservatoire des Arts et Metiers, and of projected additions. $-x$, Office for the verification of weights and measures; 2 , Laboratory of the Course of Mechanics (Prof. Tresca); 3, Ground-floor: Laboratory of the Course of Dyeing and of Ceramics (Prof. Luyne); First floor: Laboratory of Agricultural Chemistry (Prof. Boussingault); 4 Ground-floor: Amphitheatre ; First Floor: Physical Laboratory (Prof. Becquerel); 5, Provisional location of the Agronomic Institute; 6, Great Hall of Machinery in motion ; 7, Great Amphitheatre; 8. Old Amphitheatre; 9, Library ; ro, Laboratory of Industrial Chemistry (Prof. Girard); II, Laboratory of General Chemistry (Prof. Peligot); 12, Great staircase; 13, The Echo Hall; I4, Galleries and Collections; 15, Ground-floor: Gallery in construction; First floor: Gallery of Ceramics and Optics; 16 , Ground-fioor: Weights and measures; First floor: Gallery of Spinning; 17, Exhibition Hall and Gallery of Spinning; 18, Administration and Gallery in construction; 19, Industria Central School of Arts and Manufactures.

worthy of the solicitude of the Government, since it has for its object the occupation of the workers and the instruction of the people. The Conservatoire is about to make a fresh start in consequence of the construction of a new block of buildings. There is even reason to hope that these works will only be the prelude of constructions still more important, and that very soon a law will insure the completion of our fine national establishment. The following are some of the improvements which have been recently introduced into the institution.

The service of patents and of the industrial department has been recently installed in the new buildings in the rue St. Martin. Early in November there was placed at the service of the public the old and remarkable collection of Vaucanson's drawings. These drawings, which form a considerable series, comprised between the years 1775 and 1829 , have a great historical interest. We find in them the germ of a considerable number of apparatus or of systems realised in our time, and which the want of processes of execution condemned to remain in the condition of projects. We see there a great number of curious objects, and notably the original drawing of Fulton's first steamer.

Among recent additions we may mention the great gallery of machinery (No. 6 in the accompanying plan, Fig. I), to which is added the entire apse of the old

1 From an article in La Nature, by M. Gaston Tissandier.

2 Descartes had the idea of its foundation; Vaucanson formed the first germ of it by his public collection of machines, instruments and utensils, intended for the working classes and the Conventic n decided on its definitive creation by a decree of 8 vendémiaire of the year xii. 